\title{
FORMULASI DAN EFEK SALEP EKSTRAK ETANOL DAUN JAMBU BIJI (Psidium guajava,L.) DENGAN BASIS HIDROKARBON TERHADAP LUKA SAYAT PADA TIKUS JANTAN GALUR WISTAR
}

\author{
Ririn Lispita Wulandari*, Elya Zulfa, Dwara Andriani Astuti
}

Fakultas Farmasi,Universitas Wahid Hasyim

Jln. Menoreh Tengah X/22 Sampangan, Semarang

Telp.(024) 8505680

E-mail: ririnlispita@unwahas.ac.id

\section{INTISARI}

Ekstrak etanol daun jambu biji (EEDJB) terbukti menyembuhkan berbagai jenis luka.Penelitian ini bertujuan untuk mengetahui karakteristik fisikokimia salep EEDJB dengan formula basis hidrokarbon dan menguji efek salep tersebut terhadap luka sayat pada tikus jantan galur wistar.EEDJB diperoleh dengan maserasi menggunakan pelarut etanol 70\%. Salep dibuat 3 formula dengan perbandingan komposisi basis hidrokarbon (cera alba:vaselin album) yaitu $\mathrm{F} 1(2,5: 92,5) \%$; F2 (5:90)\%; F3 (7,5:87,5)\%. Karakter fisikokimia semua salep diperiksa meliputi organoleptis, homogenitas, $\mathrm{pH}$, viskositas, daya sebar, dan daya lekat.Data organoleptis, homogenitasdan pHdianalisis deskriptif, sedangkan dataviskositas, daya sebar, dan daya lekat dianalisis secara statistik.Pengujian efek 3 formula salep EEDJB dilakukan dengan cara mengoleskan 0,5 gram $2 \mathrm{x}$ sehari selama 9 haripada luka sayat buatan, dibandingkan dengan kontrol luka tanpa perlakuan dan kontrol positif menggunakan salep produk komersial. Parameter efek yang diukur adalah panjang luka sayat pada hari ke-9, kemudian dianalisis dengan uji KruskallWallisdilanjutkan Mann Whitney. Karakteristik fisikokimia salep EEDJB (F1,F2,F3)menunjukkan bahwa salep berwarna coklat, berbau khas jambu biji, homogen, $\mathrm{pH}$ sesuai $\mathrm{pH}$ kulit, viskositas dan daya lekat berbeda bermakna, sedangkan daya sebar tidak berbeda bermakna. Semua formula salep EEDJB memiliki efek terhadap luka sayat tikus jantan galur wistar yaitu panjang luka sayat pada hari ke-9 berkurang dan berbeda bermakna dibandingkan dengankontrol luka sayat tanpa perlakuan.

Kata kunci : Daun jambu biji, salep, luka sayat.

\begin{abstract}
The ethanol extract of guava leaves (EEGL) is proven to heal various types of wounds. This study aims to determine the physicochemical characteristics of the EEGL ointment with a hydrocarbon base formula and examine the effect of the ointment against cut wounds on wistar male rat. The EEGL was obtained by maceration using $70 \%$ ethanol solvent. The ointment made 3 formulas with a ratio of hydrocarbon base composition (cera alba:vaselin album) namely F1 (2.5:92.5)\%; F2 (5:90)\%; F3 (7.5:87.5)\%. The physicochemical characteristics of all ointments examined included organoleptic, homogeneity, $\mathrm{pH}$, viscosity, spreadability, and adhesion. Organoleptic, homogeneity and $\mathrm{pH}$ data were analyzed descriptively, while viscosity, spreadability and adhesion data were analyzedstatistically. Testing the effect of all ointment formulas on the wound was done by applying 0.5 gram $2 x$ a day for 9 days compared to wound control without treatment and positive
\end{abstract}


control used commercial product.The parameter of effect measured was the length of the cut wound on the 9th day, then analyzed with the Kruskall Wallis test followed by the Mann Whitney test.The physicochemical characteristics of EEGL ointment $(F 1, F 2, F 3)$ are known that all ointment formulas are brown in color, typical of guava, homogeneous, $\mathrm{pH}$ according to skin $\mathrm{pH}$, viscosity and adhesion are significantly different, while the spredability is not significant.The EEGL ointment had an effect on the cut wound of the male wistar rats, ie the length of the wound on the 9th day was reduced and compared to wound controlwas differentsignificantly.

Keywords : Guava leaves, ointment, cut of wound.

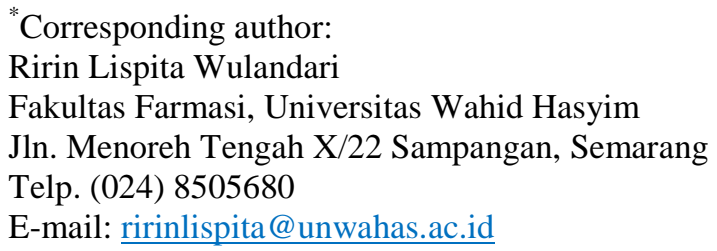

\section{PENDAHULUAN}

Luka sayat merupakan luka yang terjadi karena teriris oleh instrumen atau benda yang tajam.Penanganan standar pada luka yang dilakukan dalam dunia medis adalah dengan pemberian antiseptik, antibiotik, dan antiinflamasi. Proses penyembuhan luka merupakan proses yang kompleks, selain memerlukan efek antimikroba dan antiinflamasi, juga memerlukan mekanisme antioksidatif dan pendukung regenerasi serta proliferasi sel dalam sintesis protein dan kolagen (Berman, 2009). Penanganan luka juga dapat menggunakan caratradisional dengan memanfaatkan tumbuhan yang berkhasiat untuk menyembuhkan luka, salah satunya adalah tanaman jambu biji (Heinnermen, 2003). Daun jambu biji mengandung tanin, polifenolat, flavonoid, monoterpenoid, siskuiterpen, alkaloid, kuinon, saponin, triterpenoid dan minyak atsiri (Joseph, 2011).

Penelitian Bintarti (2014) menyebutkan bahwa ekstrak etanol daun jambu biji mengandung tanin, flavonoid, alkaloid, steroid, glikosida, dan saponin. Tanin, flavonoid dan saponin memikili kemampuan menyembuhkan luka. Tanin memiliki sifat antiseptik yang dapat mencegah pertumbuhanbakteri dengan caramerusak dinding sel sehingga menyebabkan terjadinya lisis (Nurul, 2014). Selain itu juga memiliki kemampuan sebagai antioksidan yang bekerja dengan cara menghambat peroksida lipid yang dapatmenimbulkan radikal bebas (Okuda dkk., 1992), juga dapat merangsang terjadinya angiogenesis (Li dkk., 2011) yang merupakan salah satu bagian dalam proses penyembuhan luka (Morison dan Moya, 2004). Flavonoid memiliki aktivitas antimikroba melalui pembentukan ikatan kompleks yang dapat merusak dinding sel bakteri (Fadlillah dkk., 2010),juga memiliki aktivitas inflamasi dengan cara menghambat beberapa enzim seperti: aldose reduktase, xantin oksidase, $\mathrm{CA}^{2+}$ ATPase, fosfodiesterase, lipooksigenase dan siklooksigenase (Narayana dkk., 2001). Saponin memiliki sifat bakteriostatik yang bekerja dengan merusak struktur membran sel bakteri (Minasari dkk., 2016), juga dapat memacu pertumbuhan kolagen dalam proses penyembuhan luka (Igbinosa dan Aiyegoro, 2009).

Beberapa penelitiantelah membuktikan bahwa daun jambu biji dapat menyembuhkan luka. Darsono dkk., (2003) menyebutkan bahwa ekstrak etanol daun jambu biji varietas daging buah putih terbukti mampu menyembuhkan luka infeksi Staphylococcus aureusdan hasilnya paling baik dibandingkan dengan varietas yang lain. Oktiarni dkk.(2012) membuktikan bahwa ekstrak daun jambu biji dapat menyembuhkan luka bakar pada mencit.Aponno dkk. (2014) membuktikan bahwa gel ekstrak etanol daunjambu biji memiliki efekmenyembuhkan luka sayat pada kulit kelinci yang terinfeksi Staphylococcus aureus. Penelitian Desiyana dkk.(2016) membuktikan bahwa sediaan gel

Formulasi dan Efek Salep Ekstrak Etanol Daun Jambu Biji (Psidium guajava L.) dengan Basis Hidrokarbon terhadap Luka Sayat Tikus Jantan Galur Wistar (Ririn Lispita Wulandari) 
fraksi etil asetat daun jambu biji dengan konsentrasi 5\% efektif menyembuhkan luka terbuka pada mencit.

Aplikasi ekstrak kental secara langsung pada kulit diketahui kurang nyaman dan tidak praktis, sehingga perlu dibuat menjadi suatu sediaan. Menurut penelitian Aponno dkk. (2014) selain sediaan gel, ekstrak etanol daun jambu biji dapat dibuat menjadi sediaan semisolid yang lain seperti salep yang ditujukan untuk pemakaian topikal pada kulit atau selaput lendir (Depkes RI, 1995).Yanhendri (2012) menyebutkan bahwa salep merupakan sediaan semisolid yang ditujukan untuk penggunaan pada kulit dan mukosa, serta dapat digunakan untuk menyembuhkan luka (Yanhendri, 2012). Salep mudah diaplikasikan pada kulitdandapat menjaga kelembapan kulit, tidak mengiritasi kulit serta mempunyai tampilan yang menarik (Ansel, 2005).

Pemilihan basis perlu dipertimbangkan dalam formulasi salep untuk meningkatkan efektivitas bahan aktif yang dikandungnya.Salah satu basis yang sering dipilih dalam formulasi salep kulit adalah basis hidrokarbon yang berlemak dan bersifat emolien sehingga memiliki kemampuan dapat memperpanjang waktu kontak bahan obat dengan kulit, dan dapat membuat salep tidak mudah cepat mengering dan berubah (Depkes RI, 1995).Basis hidrokarbon diantaranya adalah vaselin album dan cera alba yangberfungsi sebagai agen peningkat stabilitas salep (Kibbe, 2006). Penggunaan bahan ini dapat membuat salep memiliki sifat fisik yang baik, yaitu daya sebar salep yang besar dan lama melekat pada kulit, serta memberikan proteksi pada kulit (Pasroni, 2003).Untuk mengetahui kemampuan salep EEDJB dengan formula basis hidrokarbon terhadap penyembuhan luka sayat atau tidak, maka perlu dilakukan pengujian efek salep tersebut terhadap luka sayat tikus jantan galur wistar.

\section{METODE PENELITIAN}

\section{Bahan dan Alat Penelitian}

Bahan yang digunakan adalah daun jambu biji, etanol 70\%, basis hidrokarbon (vaselin album dan cera alba) lidokain injeksi $2 \%$, aqua pro injeksi, salep povidone iodine $10 \%$ (betadine), alkohol $70 \%, \mathrm{NaCl} 0,9 \%$ dan aquadest. Alat yang digunakan adalah alat-alat gelas, kandang mencit, neraca analitik, kain flannel, spuit $1 \mathrm{ml}$, jarum tumpul (sonde oral), stop watch, termometer, moisture content balance, bejana, rotary evaporator, cawan porselen, pot plastik,extensometer.

\section{Jalannya Penelitian}

\section{Penyiapan bahan}

Daun jambu biji yang digunakan adalah daun berwarna hijau muda, segar, bebas dari hama, dan masih utuh.Daun dicuci bersih dengan air mengalir dan kemudian dianginanginkan, lalu dikeringkan menggunakan oven dengan suhu tidak lebih dari $50^{\circ} \mathrm{C}$ yaitu $45^{\circ} \mathrm{C}$.Tujuan pengeringan simplisia adalah untuk mendapatkan simplisia yang tidak mudah rusak sehingga dapat disimpan dalam waktu relatif lama (Mursito, 2002).Simplisia kering kemudian dihaluskan dan diayak dengan ayakan nomor 100 mesh. Pemeriksaan kadar air dengan menggunakan alatmoisture content balance.Kadar air tidak lebih dari $10 \%$.

\section{Ekstraksi daun jambu biji}

Serbuk daun jambu biji diekstraksi menggunakan metode maserasi. Serbuk daun jambu biji sebanyak $2000 \mathrm{~g}$ dimasukkan ke dalam bejana, ditambah etanol 70\% sebanyak 14L. Bejana ditutup, ditempatkan pada tempat yang terlindung dari cahaya dan dibiarkan terendam selama 3 hari, sambil sesekali diaduk.Campuran serbuk simplisia dan etanol 70\% disaring. Hasil penyaringan sebagai maserat I. Ampas diremaserasi dengan etanol $70 \%$ sebanyak $6 \mathrm{~L}$ dan diberi perlakuan yang sama dengan maserasi sebelumnya selama 2 hari. Campuran serbuk simplisia dan etanol 70\% disaring kembali menghasilkan maserat II.Maserat I dan maserat II dicampur, kemudan dipekatkan menggunakan rotary evaporator dengan suhu $50^{\circ} \mathrm{C}$, sehingga diperoleh ekstrak kental daun jambu biji, kemudian dihitung rendemen ekstrak.

Formulasi dan Efek Salep Ekstrak Etanol Daun Jambu Biji (Psidium guajava L.) dengan Basis Hidrokarbon terhadap Luka Sayat Tikus Jantan Galur Wistar (Ririn Lispita Wulandari) 


\section{Pembuatan salep EEDJB}

Semua bahan yang diperlukan ditimbang sesuai perhitungan dalam formula (tabel I).Cera alba dan vaselin album dimasukkan ke dalam cawan porselen, lalu dileburkan diatas penangas air. Setelah meleleh hasil leburan dimasukkan dalam lumpang dan digerus hingga homogen. Ditambahkan ekstrak etanol daun jambu biji sedikit demi sedikit sambil digerus hingga homogen dan menjadi massa setengah padat, dimasukkan ke dalam wadah. Salep yang sudah jadi kemudian diuji karakterstik fisikokimia meliputi uji organoleptis, uji $\mathrm{pH}$, uji daya lekat, uji daya sebar dan uji efek terhadap luka sayat.

Tabel I. Formula Salep Ekstrak Etanol Daun Jambu Biji (EEDJB) 100 gram

\begin{tabular}{lccc}
\hline Bahan & F 1 (g) & F 2 (g) & F 3 (g) \\
\hline EEDJB & 5 & 5 & 5 \\
Cera alba & 2,5 & 5 & 7,5 \\
Vaselin album & 92,5 & 90 & 87,5 \\
Jumlah & 100 & 100 & 100 \\
\hline
\end{tabular}

\footnotetext{
Keterangan :

Sediaan salep EEDJB) dibuat dalam 3 formula :

F1 : mengandung cera alba \& vaselin album $(2,5 \%: 92,5 \%)$

F2 : mengandung cera alba \& vaselin album $(5 \%: 90 \%)$.

F3 : mengandung cera alba \&vaselin album $(7,5 \%: 87,5 \%)$.
}

\section{Uji karakteristik fisikokimia salep EEDJB}

a. Uji organoleptis

Sediaan salep diamati bentuk atau konsistensi, warna dan bau (Depkes RI, 2000).

b. Uji homogenitas

Sebanyak 0,5 gram salep dioleskan pada dua keping kaca atau bahan transparan lain.Sediaan salep harus menunjukkan susunan yang homogen dengan tidak terlihatnya butiran kasar (Depkes RI, 2000).

c. Uji pH

Sebanyak 0,5 gram salep dilarutkan dalam $50 \mathrm{~mL}$ aquadest. Setelah dikalibrasi alat $\mathrm{pH}$ meter dicelupkan ke dalam larutan selama 10 menit. Angka konstan yang tertera pada skala $\mathrm{pH}$ meter merupakan nilai $\mathrm{pH}$ dari sediaan (Depkes RI, 2000).

d. Viskositas

Sebanyak 100 gram sediaan salep dituang ke dalam wadah, selanjutnya dipasang spindelyang diturunkan ke dalam sediaan sampai batas yang ditentukan dan rotor dinyalakan.Pengukuran yang dilakukan menggunakan kecepatan tertentu.Pengukuran dengan perbedaan rpm dibaca skalanya ketika jarum penunjuk skala telah stabil (Voigt, 1984).

e. Uji daya lekat

Sebanyak 0,5 gram salep diletakkan di atas gelas obyek yang telah ditentukan luasnya. Kemudian diletakkan gelas obyek lain di atas sediaan salep tersebut. Setelah itu ditambahkan beban $1 \mathrm{~kg}$ selama 5 menit pada gelas obyek lalu dipasang pada alat tes.Kemudian beban seberat 80 gram dilepaskan, dan dicatat waktunya hingga kedua gelas obyek tersebut terlepas (Voigt, 1984).

f. Uji daya sebar

Sebanyak 0,5 gram salep diletakkan pada alat uji extensometer, diletakkan diatas kaca bulat dengan diameter $15 \mathrm{~cm}$, kaca lainnya diletakkan diatasnya kemudian dibiarkan selama 1 menit. Diameter sebar salep diukur.Setelah pengukuran diameter salep, 50 gr beban ditambahkan dan didiamkan selama 1 menit lalu diukur diameter yang konstan

Formulasi dan Efek Salep Ekstrak Etanol Daun Jambu Biji (Psidium guajava L.) dengan Basis Hidrokarbon terhadap Luka Sayat Tikus Jantan Galur Wistar (Ririn Lispita Wulandari) 
sampai tidak terjadi penambahan diameter dan dilakukan pencatatan data (Voigt, 1984).

\section{Penyiapan hewan uji}

Hewan uji yang digunakan adalah 25 ekor tikus jantangalur Wistar, umur 2-3 bulan, BB 180200 gram, bergerak aktif, dan kulit tidak ada kelainan morfologi,dibagi menjadi lima kelompok, yang ditempatkan pada kandang terpisah.Sebelum dilakukan percobaan hewan uji diaklimatisasi selama 7 hari.

\section{Pengujian efek salep EEDJB terhadap luka sayat tikus}

Seluruh tikus dicukur terlebih dahulu pada punggungnya berdiameter kurang lebih $3 \mathrm{~cm}$ dengan spidol untuk memudahkan pengamatan.Daerah yang dicukur bulunya didesinfeksi menggunakan alkohol $70 \%$, lalu diberikan anestesi lidokain secara intra muscular.Punggung tikus dilukai sepanjang $2 \mathrm{~cm}$ dan kedalaman $0,2 \mathrm{~cm}$. Luka dibersihkan dengan dialiri $\mathrm{NaCL}$ 0,9\% fisiologis menggunakan spuit $5 \mathrm{ml}$ sampai perdarahan berhenti. Selanjutnya luka dikeringkan dengan kasa steril dengan gerakan sirkulet dari dalam ke luar (Eriadi, 2015).Setelah itudiberi perlakuaan sesuai dengan kelompok masing-masing (tabel II).

Tabel II. Kelompok hewan uji

\begin{tabular}{ll}
\hline \multicolumn{1}{c}{ Kelompok } & \multicolumn{1}{c}{ Perlakuan } \\
\hline $\begin{array}{l}\text { Kontrol luka tanpa } \\
\text { perlakuan }\end{array}$ & Luka sayat tidak diberi salep EEDJB \\
Kontrol positif & Luka sayat diberi salep produk komersial \\
KF1 & Luka sayat diberi salep EEDJB formula 1 \\
KF2 & Luka sayat diberi salep EEDJB formula 2 \\
KF3 & Luka sayat diberi salep EEDJB formula 3 \\
\hline
\end{tabular}

Kontrol positif, KF1, KF2, KF3 diberi salep 0,5 g 2 kali sehari selama 9 hari. Panjang luka sayat $(\mathrm{mm})$ diamati menggunakan jangka sorong.

\section{Analisis data}

Data hasil uji organoleptis, homogenitas dan $\mathrm{pH}$ dianalisis secara deskriptif. data hasil uji daya lekat, daya sebar dan viskositas dianalisis statistik menggunakan uji Kruskal Wallis, dilanjutkan uji Mann Whitney.

Data panjang luka sayat $(\mathrm{mm})$ semua kelompok hewan uji pada hari ke-9 dianalisis statistik dengan uji Kruskal Wallis dilanjutkan Mann Whitney,

\section{HASIL DAN PEMBAHASAN}

Organoleptis Salep EEDJB

Hasil pemeriksaan organoleptis dapat dilihat pada tabel III sebagai berikut:

Tabel III. Hasil Uji Organoleptis Salep EEDJB

\begin{tabular}{cccc}
\hline Parameter & F 1 & F 2 & F 3 \\
\hline Bentuk & Lembut & Lembut & Lembut \\
Bau & Khas & Khas & Khas \\
Warna & coklat & coklat & Coklat \\
\hline Keterangan : & \multicolumn{3}{l}{} \\
F1 : Formula salep komposisi cera alba : vaselin album $(2,5 \%: 92,5 \%)$ \\
F2 : Formula salep komposisi cera alba : vaselin album $(5 \%: 90 \%)$. \\
F3: Formula salep komposisi cera alba : vaselin album $(7,5 \%: 87,5 \%)$.
\end{tabular}

Formulasi dan Efek Salep Ekstrak Etanol Daun Jambu Biji (Psidium guajava L.) dengan Basis Hidrokarbon terhadap Luka Sayat Tikus Jantan Galur Wistar (Ririn Lispita Wulandari) 


\section{Homogenitas Salep EEDJB}

Pengujian homogenitas dilakukan untuk memastikan seluruh bahan-bahan dalam formula salep bercampur merata atau tidak ada gumpalan maupun butiran kasar yang dapat membuat kulit menjadi iritasi (Voigt, 1984).

Hasil pengujian homogenitas salep EEDJB (tabel IV) menunjukan semua salep tersebut homogen, ditandai dengan tidak adanya butiran kasar atau partikel yang bergerombol pada objek gelas, dan menyebar secara merata.

Tabel IV. Hasil Uji Homogenitas Salep EEDJB

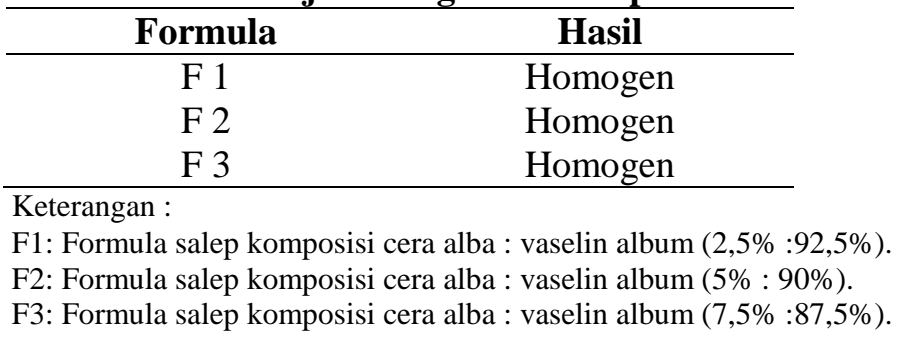

\section{Viskositas Salep EEDJB}

Pengujian viskositas EEDJB dilakukan untuk mengetahui konsistensi sediaan salep EEDJB yang telah dibuat. Hasil pengujian tersebut dapat dilihat pada tabel V.

Tabel V. Hasil Uji Viskositas Salep EEDJB

\begin{tabular}{cc}
\hline Formula & Rata - rata viskositas \pm SD \\
\hline F 1 & $73,33 \pm 4,71^{*}$ \\
F 2 & $103,33 \pm 9,43^{*}$ \\
F 3 & $126,66 \pm 0,00^{*}$ \\
\hline
\end{tabular}

Keterangan :

F1: Formula salep komposisi cera alba : vaselin album $(2,5 \%: 92,5 \%)$.

F2: Formula salep komposisi cera alba : vaselin album $(5 \%: 90 \%)$.

F3: Formula salep komposisi cera alba : vaselin album $(7,5 \%: 87,5 \%)$.

*: berbeda bermakna $(p<0.05)$, (uji Mann Whitney)

Tabel di atas menunjukkan bahwa perbedaan komposisi basis dalam F1, F2, F3, menghasilkan perbedaan viskositas salep secara signifikan $(p<0.05)$. Basis cera alba memiliki sifat lebih keras dan peningkat stabilitas dalam sediaan sehingga meningkatan konsistensi salep (Depkes RI, 1995).Viskositas berhubungan dengan kemampuan penyebaran salep pada kulit dan kenyamanan saat pemakaian. Salep dengan viskositas yang rendah akan memudahkan pengambilan salep dari wadah sehingga memudahkan saat pemakaian (Marchaban, 1993).

\section{Daya Sebar Salep EEDJB}

Daya sebar salep menunjukkan kemampuan salep untuk terdistribusi merata pada permukaan kulit. Daya sebar dapat mempengaruhi kecepatan difusi zat aktif melewati membran kulit (Hasyim, 2012). Hasil uji daya sebar salep EEDJB dapat dilihat pada tabel VI. Berdasarkan hasi uji statistik Kruskal Wallis, tidak ada perbedaan bermakna di antara daya sebar salep ketiga formula. Perbedaan komposisi basis tidak berdampak pada daya sebar salep, meskipun ada peningkatan viskositas dari F1 sampai F3. 
Tabel VI. Hasil Uji Daya Sebar Salep EEDJB

\begin{tabular}{cc}
\hline Formula & Rata - rata nilai daya sebar $\pm \mathbf{S D}\left(\mathbf{c m}^{2}\right)$ \\
\hline F 1 & $2,56 \pm 0,052^{*}$ \\
F 2 & $2,47 \pm 0,065^{*}$ \\
F 3 & $2,32 \pm 0,078^{*}$ \\
\hline
\end{tabular}

Keterangan :

F1: Formula salep konsentrasi cera alba : vaselin album $(2,5 \%: 92,5 \%)$.

F2: Formula salep konsentrasi cera alba : vaselin album (5\%:90\%).

F3: Formula salep konsentrasi cera alba : vaselin album $(7,5 \%: 87,5 \%)$.

*: berbeda tidak bermakna ( $p>0.05)$ (uji Kruskall Wallis)

\section{Daya Lekat}

Pengujian daya lekat salep dilakukan untuk mengetahui lama waktu pelekatan salep terhadap permukaan kulit. Hasilnya dapat dilihat pada tabel VII di bawah ini :

Tabel VII. Hasil Uji Daya Lekat Salep EEDJB

\begin{tabular}{cc}
\hline Formula & \multicolumn{1}{c}{ Rata - rata nilai daya lekat $\pm \mathbf{S D}($ detik) } \\
\hline F 1 & $3,69 \pm 0,29^{*}$ \\
F 2 & $4,60 \pm 0,30^{*}$ \\
F 3 & $5,87 \pm 0,53^{*}$ \\
\hline Keterangan : \\
F1 : Formula salep komposisi cera alba : vaselin album $(2,5 \%: 92,5 \%)$. \\
F2 $\quad$ : Formula salep komposisi cera alba $:$ vaselin album $(5 \%: 90 \%)$. \\
F3 : Formula salep komposisi cera alba : vaselin album $(7,5 \%: 87,5 \%)$. \\
*: berbeda bermakna $(p<0.05),($ uji Mann Whitney)
\end{tabular}

Pada tabel VII di atas dapat diketahui bahwa perbedaan komposisi basis salep pada F1, F2 dan F3, menghasilkan daya lekat yang berbeda bermakna dan cenderung meningkat dari F1 hingga F3. Hal ini menunjukkan terdapat hubungan atau pengaruh antara viskositas dengan daya lekat seperti yang disebutkan oleh Voigt (1984) bahwa semakin tinggi viskositas salep, dapat meningkatkan daya lekat sediaan tersebut.

\section{pH Salep EEDJB}

Pengujian $\mathrm{pH}$ dilakukan untuk mengetahui kestabilan sediaan salep, karena profil $\mathrm{pH}$ dapat menentukan stabilitas zat aktif dalam keadaan suasana asam atau basa (Lachman dkk., 1994). Nilai $\mathrm{pH}$ yang melebihi 7 dapat menyebabkan iritasi kulit, sedangkan $\mathrm{pH}$ kulit normal yaitu antara 4,5 6,5 (Gadekar dkk., 2012). Hasil uji pH salep EEDJB dapat dilihat pada tabel VIII berikut ini :

Tabel VIII. Hasil Uji pH Salep EEDJB

\begin{tabular}{cc}
\hline Formula & Rata - rata nilai $\mathbf{p H} \pm$ SD \\
\hline F 1 & $4,60 \pm 0,30$ \\
F 2 & $4,99 \pm 0,35$ \\
F 3 & $5,53 \pm 0,38$ \\
\hline
\end{tabular}

Keterangan :

F1: Formula salep komposisi cera alba : vaselin album $(2,5 \%: 92,5 \%)$.

F2: Formula salep komposisi cera alba : vaselin album $(5 \%: 90 \%)$.

F3: Formula salep komposisi cera alba : vaselin album $(7,5 \%: 87,5 \%)$.

Formulasi dan Efek Salep Ekstrak Etanol Daun Jambu Biji (Psidium guajava L.) dengan Basis Hidrokarbon terhadap Luka Sayat Tikus Jantan Galur Wistar (Ririn Lispita Wulandari) 
Berdasarkan tabel VIII tiap formula salep memiliki pH yang memenuhi persyaratan yaitu tidak kurang dari 4,5 dan tidak lebih dari 6,5.

\section{Efek Salep EEDJB terhadap Luka Sayat Tikus}

Parameter untuk mengetahui efek EEDJB terhadap luka sayat tikus adalah panjang luka sayat yang diukur pada hari ke-9. Data hasil pengukuran panjang luka sayat pada hari ke 9 salep EEDJB dapat dilihat pada gambar 1 sebagai berikut:

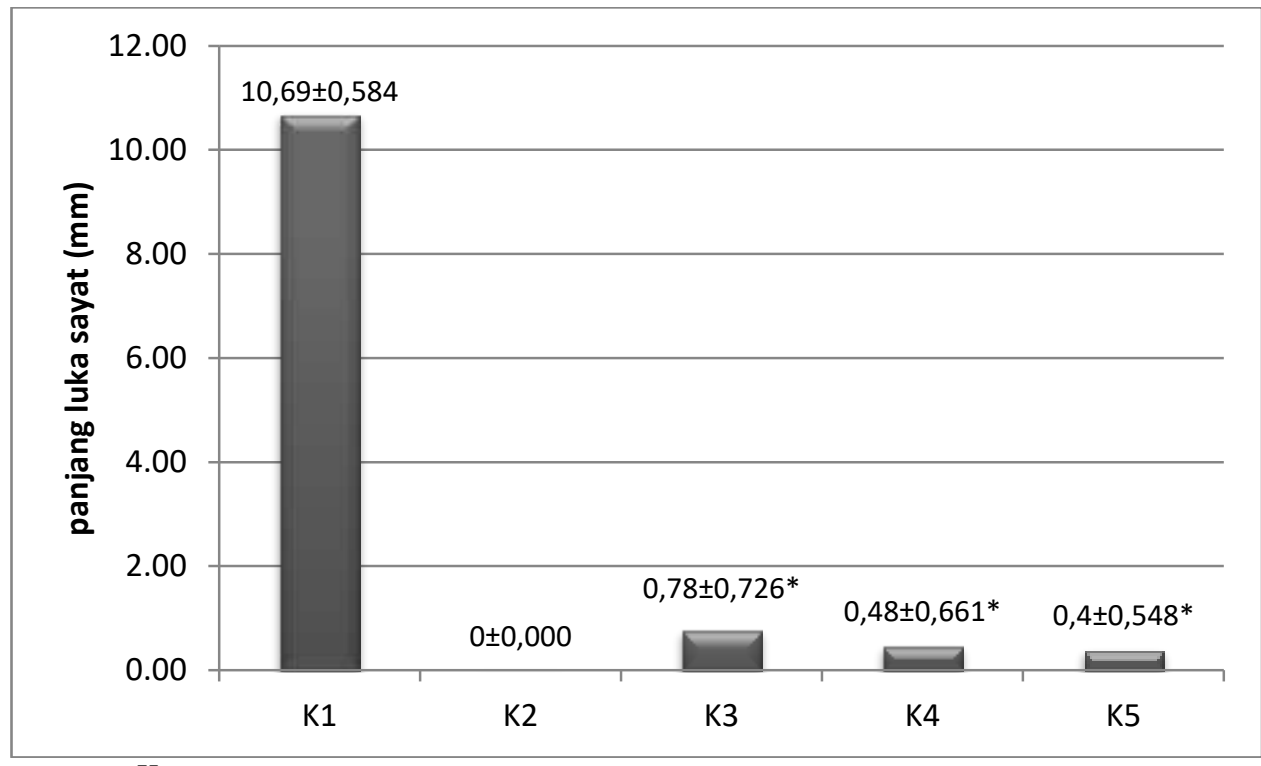

\footnotetext{
Keterangan :

K 1 : kontrol luka tanpa perlakuan

$\mathrm{K} 2$ : kontrol positif salep betadine

K 3 : salep EEDJB F1 (cera alba : vaselin album $(2,5 \%$ : 92,5\%)

$\mathrm{K} 4$ : salep EEDJB F2 (cera alba : vaselin album(5\%: $90 \%)$

K 5 : salep EEDJB F3 I(cera alba : vaselin album(7,5\%:87,5\%)

$*=$ berbeda bermakna dengan kontrol luka tanpa perlakuan $(p<0.05)$
}

Gambar 1. Rata-rata panjang luka sayat tikus pada hari ke-9

Berdasarkan grafik di atas diketahui bahwa panjang luka sayat tikus pada hari ke-9 setelah pemberian salep EEDJB F1, F2, F3 berkurang dan berbeda bermakna dibandingkan dengan kontrol luka tanpa perlakuan. Hal ini menunjukkan bahwa semua salep tersebut memiliki efek terhadap luka sayat tikus. Kontrol positif (salep betadin) mampu menyembuhkan luka sayat berdasarkan hasil telah menutupnya luka (terukur panjang luka sayat sebesar $0 \mathrm{~mm}$ ). Hal tersebut terjadi karena salep mengandung povidon iodin $10 \mathrm{mg}$ yang dapat membunuh kuman, bakteri dan virus tanpa menyebabkan kekebalan terhadap kuman tersebut (Scalbert, 1991).

Berkurangnya panjang luka sayat pada tikus setelah pemberian salep EEDJB diduga disebabkan karena EEDJB mengandung tanin, flavonoid dan saponin. Bintarti (2014) membuktikan bahwa ekstrak etanol daun jambu biji mengandung tannin, flavonoid, dan saponin. Flavonoid dapat membantu proses penyembuhan luka sayat. Senyawa tersebut memiliki efek antiinflamasi yang berfungsi sebagai anti radang dan mampu mencegah kekakuan dan nyeri. Senyawa tersebut mampu menghambat cyclooxygenase yang memberikan efek anti inflamasi dan menurunkan fragilitas kapiler sehingga meningkatkan kekuatan jaringan ikat dan mengurangi terjadinya kebocoran kapiler ke interstitial, sehingga akan mencegah terjadinya edema (Mills dan Bone, 2013).

Formulasi dan Efek Salep Ekstrak Etanol Daun Jambu Biji (Psidium guajava L.) dengan Basis Hidrokarbon terhadap Luka Sayat Tikus Jantan Galur Wistar (Ririn Lispita Wulandari) 
Saponin mempunyai kemampuan sebagai pembersih dan antiseptik yang berfungsi membunuh atau mencegah pertumbuhan dari mikroorganisme yang timbul pada luka sehingga luka tidak mengalami infeksi yang berat.Saponin juga memiliki aktivitas antiinflamasi yang dapat mengurangi edema dan inflamasi pada kulit (Kim dkk., 2011). Tanin bersifat anti bakteri yang mampu berikatan membentuk kompleks dengan enzim bakteri ataupun substrat kemudian memasuki sel bakteri melalui dinding sel bakteri yang menyebabkan denaturasi protein sehingga terjadi kerusakan dinding sel yang menyebabkan sel lisis.

\section{KESIMPULAN}

Salep EEDJB memiliki tekstur yang lembut, bau khas daun jambu biji, berwarna coklat dan homogen pada ketiga formula salep, serta memiliki $\mathrm{pH}$ memenuhi persyaratan yaitu 4,5 6,5.Variasi komposisi basis hidrokarbon menghasilkan perbedaan viskositas dan daya lekat yang bermakna, namun daya sebar berbeda tidak bermakna. Salep EEDJB memiliki efek terhadap luka sayat tikus yaitu panjang luka sayat berkurang dan berbeda bermakna dibandingkan dengan kontrol luka tanpa perlakuan.

\section{DAFTAR PUSTAKA}

Ansel, H. C., 2005, Pengantar Bentuk Sediaan Farmasi, diterjemahkan oleh Ibrahim, F., Jakarta, Penerbit UI Press, 605-619.

Aponno, J. V., Paulina V. Y. Yamlean, dan Hamidah S. Supriati. 2014. Uji Efektivitas Sediaan Gel Ekstrak Etanol Daun JambuBiji (Psidium guajava, Linn.) terhadap Penyembuhan Luka yang Terinfeksi Bakteri Staphylococcus aureus pada Kelinci (Orytolagus cuniculus), Pharmacon.3 (3), 279-285.

Berman, A., 2009, Buku Ajar Praktik Keperawatan Klinis Edisi Kelima, Penerbit Buku Kedokteran EGC, Jakarta, 795.

Bintarti, T., 2014, Skrinning Fitokimia dan Uji Kemampuan Sebagai Antioksidan dari Daun Jambu Biji (Psidium guajava L), Jurnal Ilmiah PANMED, 9 (1), 40-44.

Darsono, F. L., Artemisia, S. D., 2003, Aktivitas antimikroba ekstrak daun jambu biji dari beberapa kultivar terhadap Staphylococcus aureus ATCC 25923 dengan "hole-plate diffusion method",Berk. Penel. Hayati, 9, 49-51

Depkes RI, 1995, Farmakope Indonesia, edisi IV, Departemen Kesehatan Republik Indonesia, Jakarta, 175, 413.

Depkes RI., 2000, Parameter Standar Umum Eksrak Tumbuhan, Jilid I, Departemen Kesehatan Republik Indonesia, 3-10, 13-24.

Desiyana, L. S., Husni,M. A., dan Zhafira, S., 2016, Uji efektivitas sediaan gel fraksi etil asetat daun jambu biji terhadap penyembuhan luka terbuka pada mencit (Mus musculus), Jurnal Natural, 16 (2), 1-7.

Eriadi, A.,2015, Pengaruh Ektrak Etanol Daun Binahong terhadap pernyembuhan luka sayat pada tikus jantan, Jurnal Farmasi Higea, 7 (2), 162-172.

Fadlillah, R., Handajani, J., dan Haniastuti, T., 2010, Ekstrak Daun JambuMete Konsentrasi 10\% yang Dikumurkan dapat Menghambat PertumbuhanStreptococcus mutansSaliva, Dentika Dental Journal, 15, 135-140.

Gadekar, R., Saurabh, M. K., Thakur, G. S., dan Saurabh, A., 2012, Studi of Formulation, Characterisation and Wound Healing Potential of Transdermal Patches of Curcumin, Asian Journal of Pharmaceutical and Clinical Research,5(4), 225-230.

Hasyim N, Pare I, Junaid A, Kurniati., 2012, Formulasi dan uji Efektivitas Gel Luka Bakar Ekstrak Daun Cocor Bebek (Kalanchoepinnata L.) pada Kelinci (Oryctolagus cuniculus),Majalah Farmasi dan Farmakologi, 16(2),89-94

Formulasi dan Efek Salep Ekstrak Etanol Daun Jambu Biji (Psidium guajava L.) dengan Basis Hidrokarbon terhadap Luka Sayat Tikus Jantan Galur Wistar (Ririn Lispita Wulandari) 
Heinnermen, J., 2003, Khasiat Jambu Biji Manfaat Medis Jambu Biji BagiKesehatan Anda, Penerbit Prestasi Pustakakarya, Jakarta, 23.

Igbinosa E.O., dan Aiyegoro, O.A., 2009, Antimicrobial Activity and Phytochemical Screening of Steam Bark Extracts from Jatropha curcas (Linn), African Journal of Pharmacy and Pharmacology, 3(2), 058-062.

Joseph, B., 2011, Review on Nutritional, Medicinal, and Pharmacological Properties of Psidium guajava Linn, Internantional Journal of Pharma and Bio science, 2 (1), 53-69.

Kibbe, A. H., 2006, Handbook Of Pharmaceutical Excipients,5th Edition, Phamaceutical Press London, United Kingdom dan American Pharmaceutical Association, Washington, D. C, 214- 216.

Kim YS., Cho IH., Jeong MJ., Jeong SJ., Nah SY., Cho YS.,2011. Therapeutic effect of total ginseng saponin on skin wound healing. Journal-of-Ginseng-Research, 35 (3), 360-367.

Lachman, L., Lieberman, H. A., dan Kanig, J. L., 1994, Teori dann Praktek Farmasi Industri, Edisi III, diterjemahkan oleh Suyatmi, S., Universitas Indonesia Press, Jakarta, 1091-1095, 11121118.

Li, K., Dao, Y., Zhang, H., Wang, S., Zhang, Z., Yu, B., Huang, S., dan Yang, H., 2011, Tannin Extracts from Immature Fruits of Terminalia chebula Fructus Retz Promote Cutaneous Wound healing in rats, BMC Complementary and Alternative Medicine, 15.

Marchaban, 1993, Efisiensi Krim Hidrokortison Secara In-Vitro, Majalah Farmasi Indonesia, 4 (2), 61-67.

Mills, S., dan Bone, K., 2013, Principles of herbal pharmacology, In : principles and practice of phytotherapy modern herbal medicine, New York : Churchill Livingstone, 31-3.

Minasari, Amelia, S.,Sinurat, J.2016, Efektivitas Ekstrak Daun Jambu Biji terhadap Pertumbuhan Staphylococcus aureus, Makassar Dental Journal, 5 (2), 34-39.

Morison dan Moya, J., 2004.Manajemen luka. Jakarta: EGC. 1-5

Mursito, B., 2002.,Ramuan Traditional Untuk Pengobatan Jantung, Cetakan II, Penerbit Pebar Swadaya, Jakarta, 3, 7-8, 11-2

Narayana, K. R., Reddy, M.R, dan Chaluvadi, M. R., 2001, Bioflavonoids Classification, Pharmacological, Biochemical Effects and Therapeutic Potential, Indian Journal Pharmacology, 33(1), 2-16.

Nurul, R., 2014, Uji Efektivitas Antibakteri Infusum Daun Jambu Biji (Psidium guajava Linn.) terhadap Pertumbuhan Bakteri Penyebab Karies Streptococcus mutanssecara In Vitro, Skripsi, Universitas Andalas.

Okuda, T., Yoshida, T., dan Hatano, T., 1992, Chemical and Biological Activity of Tannin in Medical Plants Research, Edited by Wagner and Dorman, Academic Press, 129 - 165.

Oktiarni D, Manaf S, Suripno. 2012. Pengujian Ekstrak Daun Jambu Biji (Psidium guajava linn) Terhadap Penyembuhan Luka Bakar pada Mencit (Mus musculus), Jurnal Gradien,8(1), $752-755$.

Pasroni, 2003, Pengaruh Tipe Basis Salep Terhadap Pelepasan Zat Aktif Minyak Atsiri Temu Ireng (Curcuma aeruginosa Roxb.) Sebagai Antijamur Secara In Vitro, Skripsi, Fakultas Farmasi, Universitas Muhammadiyah Surakarta.

Scalbert, A. 1991, Antimicrobial Properties of Tannins, Phytochemistry, 30 (12), 83.

Voigt, R., 1984, Pelajaran Teknologi Farmasi, Edisi V, diterjemahkan oleh Soewandi Noerono Soewandhi, Gadjah Mada University Press, Yogyakarta, 394, 562-581.

Yanhendri SWY., 2012, Berbagai Bentuk Sediaan Topikal dalam Dermatologi, Cermin Dunia Kedokteran, 39 (6),423-430.

Formulasi dan Efek Salep Ekstrak Etanol Daun Jambu Biji (Psidium guajava L.) dengan Basis Hidrokarbon terhadap Luka Sayat Tikus Jantan Galur Wistar (Ririn Lispita Wulandari) 